\section{SOI: $1.1 /$ TAS DOI: $10.15863 /$ TAS International Scientific Journal Theoretical \& Applied Science}

p-ISSN: 2308-4944 (print) e-ISSN: 2409-0085 (online)

Year: $2015 \quad$ Issue: 08 Volume: 28

Published: $30.08 .2015 \quad$ http://T-Science.org
Anna Vladimirovna Shutaleva Candidate of philosophical sciences, associate professor of ontology and theory of knowledge, Ural Federal University ashutaleva@yandex.ru

Evgeniya Anatol'evna Putilova

Candidate of philosophical sciences, associate professor of humanitarian and social and economic education, Nizhny Tagil institute of technology, Ural Federal

University eazhiltsova@mail.ru

\title{
DIALOGUE AS A STRATEGY IN MODERN EDUCATIONAL SPACE
}

Abstract: In article such actual perspective for Russia of the XXI century as possibility of application of problem and dialogue strategy in modern educational space is analyzed. The special attention is paid to problems of influence of education on formation of the human person and indicators of efficiency of education. Competencebased approach allows to designate an adaptation context in a system "personality-society» which staticizes uniqueness of an inclusiveness of the personality in educational process.

Key words: dialogue, competence-based approach, education, rating, personality.

Language: English

Citation: Shutaleva AV, Putilova EA (2015) DIALOGUE AS A STRATEGY IN MODERN EDUCATIONAL SPACE. ISJ Theoretical \& Applied Science 08 (28): 115-118.

Soi: http://s-o-i.org/1.1/TAS-08-28-21 Doi: crossef http://dx.doi.org/10.15863/TAS.2015.08.28.21

Introduction. One of the defining features of the modern world is a common imbalance in the relationship of the natural environment and human development. Imbalance is associated with scientific and technological progress and threatens crises of axiological nature. The aggravation of social contradictions and changing picture of the world associated with the changes in the representation of values in social structures and educational space has led. The University loses its cultural function and loses its status as a model of society that leads to the crisis of the foundations of the idea of the University. B. Ridings in the "University in ruins», which characterizes the modern University as «posthistorical», believes that he ceases to participate in the «historical project of humanity» [8, c. 26] both survived. Confirmation of this statement he sees that the modern University is losing its role, its function «by the manufacturer, the protector and propagator of the idea of national culture» [8, c. 24]. In the last decade of the twentieth century was aware of the exhaustion of the social doctrines of the device aimed at practical results, for example, the concept of «social state», "social market economy», national models (Swedish, Israeli, Japanese, South Korean, etc.). At the UN Conference on environment, held in June 1992 in Rio de Janeiro, in which the leaders of 179 countries recognized that the Western model of civilization development is not just exhausted, but can be seen as leading to social, economic and environmental disaster. As an alternative adopted the «sustainable development strategy», based on the interaction and harmony of the triad «Man - Society - Nature».

Dialogue as a strategy in modern educational space. A new strategy must be reflected in the education system. In the research literature on the subject emphasizes the humanistic nature of the dialogue as a strategy in the education system. So, Novozhenina E. V. notes that «The structure of the dialogue fills the process of education of a humanitarian sense» [6, p. 99]. Semenova, Y. L. emphasizes that «The use of the dialogue of cultures as a resource of formation of communicative competence gives educational process of personalactivity orientation. This resource involves the learning of all participants in the educational process ability to listen and question, to accept and to doubt, to wonder and admire, argue and persuade» $[9, \mathrm{p}$. 90-91].

Questioning is actualized in the dialogue not as a representation but as a semantic horizon. This provision justifies the prospective nature of the dialogue, since mind emanates from certain ontological foundations that contribute to the implementation of understanding by the participants of the dialogue of an issue. According to the system of sustainable development, the role of education lies not only in the process of updating and spreading knowledge. Education is a social institution which is regarded as the main instrument of implementation sustainable development concept, which determines the relationship of the concepts of education and a new model of civilization development. In psycho- 
pedagogical aspect, it is possible to trace a close connection to individual human development and how the process of «mastering» living environment that involves the assimilation of norms, patterns and principles of organization of external space and time [3]. As noted by V. G. Lankin, E. E. Lankina «Personal meaning in the competence approach means the adaptation of the individual to society, not a rethinking of sociality in the coordinate system of the human personality» $[4, \mathrm{p} .10]$. For the modern concept of education is characterized by a recognition of the uniqueness is included in this process of personality and individuality educational trajectories. The educational process has a significant impact on the entry of a person into the socio-cultural space, the nature of man's relationship with the environment in the aspect of its value perception, which is important in the analysis of features of modern educational process. For modern education becomes important indicator of efficiency, the degree of which is reflected in various rankings. Fair is a point of view E. V. Bakeeva, which in the article "The Ontological context of the ideology of the rating», notes that the process of «hierarchical ordering has a distinctly evaluative connotation and, thus, has the ability of ideological influence» $[1, \mathrm{p}$. 107]. The rating interpretation of E. V. Bakeeva as «backup», «which can perform its guiding function only take into account its secondary and simulation, «nature», if there is hypostatizations of this secondary reality» [1, p. 111]. Educational space becomes effective only when the perception of his subject as meaningful, valuable for its personal selfregulation and self-development. Dialogue as a strategy in the modern educational space is associated not only with the broadcast of knowledge, but the creation of a unique space in the learning process. This unique space is creative and requires not only knowledge of learning technologies, but also creativity. As rightly pointed out by O. N. Tomuk, «Creativity, as a form of change, renewal, is, on the one hand, continuation of evolutionary and nonstationarity, and, on the other hand, has its own foundation - consciousness. In ontological terms creativity is the synthesis of natural development potentials of being and human's creative activity with the presence of unconscious and conscious, casual and indispensable» [11, p. 1295]. Full development and healthy functioning of the human psyche that are included in the educational process at all levels is open, intense interaction, dialogical in nature.

B. Ridings, criticizing traditional attitudes towards the University as to the «chief of the national Institute of culture», holds «structural diagnosis of the modern transformation of the institutional function of the University» [8, c. 22]. "The University in ruins» is an attempt to analyze the changing role of the University. The University must become a «place of mind», a place where think together, but not uniformly: «No authority is not able to interrupt the pedagogical relationship, there is no knowledge is able to deliver us from the task of thinking... Posthistorical University is likely to abandon aspirations to join the authority and autonomy in the community rallied around some ideas» [8, c. 202]. First, according to B. Ridings goes «institutional pragmatism», i.e. the recognition that a modern University «is an institution that loses the need for a transcendental justification of its functions» [8, c. 220]. The idea of «posthistorical» the University, he describes using three ideas: first, the education has no boundaries; secondly, the University is not only reproduced the system of professional competence, but also constantly demonstration of borders; thirdly, the creation of dissensual community. Plan B. Ridings «is the antimodern redefinition of teaching and learning... as arenas of ethical practices, not as a means of transmission of scientific knowledge. In this case, the teaching begins to answer the question of justice and not the criteria of truth. We must learn the teaching, and give him justice» [8, p. 202]. Teaching as dialogue necessarily involves the practice of problematic interpretation of educational material, which, according to O. I. Vaganova, «is that the teacher does not give knowledge in finished form, but puts students problems, prompting them to seek ways and means of solving them. The problem itself paves the way for new knowledge and methods of action. Fundamentally important is the fact that new knowledge is not provided for the information and for solving the problem or problems» [2, p. 10]. Traditional pedagogical strategy based on «consumption» ready-made science does not lead to the formation in the minds of students the model of future real activity [2, p. 10].

A fundamental feature of the equilibrium linking personality with the surrounding life and educational space dialog is mediating the relationship of personality with the environment, which, as noted by Y. S. Pesockii, can be considered as the context of the theory of social metabolism (the harmonization of relations with the environment) [7]. This conception is fundamental to accountabilities the vision of the world that leads to the inclusion of views about the optimal ways and means of metabolism, which involves the harmonization of information environment and the value-orientation of priorities. Value meanings in the personality structure manifested in the peculiarities of its adaptation, which is possible thanks to the technology of active development. As noted by E. V. Bakeeva, «recognition of the existence of the sphere of real being, grasped by the mind, as opposed to a rational calculus of the sphere of various «illusions» incompatible with the ideology of the rating, shall not act as its ontological context. Thus, it is 
necessary to assume that moving from the periphery to the center of attention of modern man as its ontological Foundation can have no claim, but, on the contrary, the negation of being as that "really are"ı»» [1, p. 109]. Problem of the dialog strategy of teaching allows to revive the tradition of pedagogy of dialogue in action, founded by Socrates, for whom blending dialogism, philosophy and education. Dialogue is a unique space of meaning where the learner plays an active role that allows to create what «did not exist», a new. In this regard, important in the process of learning becomes the vector of development of learning process that involves the creative process as "... as a birth process of the new, is directed from nothingness to being: creativity is not simply multiply the diversity of forms of existence, but also generates a fundamentally new things, gives a qualitative extension of the current being. "The new" is the arising and becoming being» [11, p. 1294]. The need for studies using nonclassical ways of describing the mechanisms of Constitution of objectivity, where the decisive is the concept of «dialogue» is determined by what the «vision» enriches the consciousness of life value and is regarded as a fundamental principle in the study of human nature and the ontological structures [10]. In this regard, we agree with the opinion Tomyuk O. N. that «Creativity and lawmaking in the ontological aspect appear as a universal human ability to transformation, changing and improving of existence and his own development, in other words, in the creative process human builds himself, creates his own personality» [11, p. 1298]. The dialogue is an opportunity, which gives a person the ability to be «inside» meaning, in co-existence, which is always the consistency and meaningfulness, experienced and lived in a joint «space». Dialogue is a joint presence, co-existence that breeds, including in the educational space of the mode of this presence.

The dialogue is what makes a person is embedded in the learning process. The dialogue is associated with the space of being, having and event in nature, in which the consciousness is embodied in the prospects of its ongoing vision. Thus, a possible basis for defining the space of learning, in which consciousness acts as a universal interoperability, thanks to which «possible» becomes «real». A certain value or meaning always occurs in connection with a specific event or state of affairs, however, any circumstance acts as a «state of affairs» only when it is given a certain range of meanings, i.e. fixed «availability» constitutive, meaning «the system»the consciousness of the person involved in coexistence with another person. The understanding of dialogue as a co-existence connected with Athenian to another person as a value that actualizes the problem of patience, tolerance in the educational process. As noted by A. V. Loginov, «tolerance is a contradictory value, requires some effort to his incarnation... tolerance is possible in two cases: first, when there is reason, "outweighing" your moral objections deviation (for example, when a person is very important for the community) - but this ground is not tenable; secondly, when triggers the shift in attention that have caused moral rejection (for example, lifestyle), on the human right to choose your lifestyle - i.e., this type of argumentation, which, from the point of view of the defenders of liberalism, is most acceptable these days» [5].

Conclusion. The theme of dialogue as a strategy in the modern educational space leads to the comprehension of the value of life of the individual. Modern social space asserts the inevitability of many millions and the infinite process of interpretation, the existence of many non-identical to each other, but quite the equal of phenomena, is able to engage in dialogue. This is a critical challenge for Russia in the early twenty-first century, as the ongoing reassessment of values affects the system of Russian culture and education in the conceptual foundations of the vision of the outer world in the aspects of the transient and the eternal, for knowledge, unfolding the meaning is problematized in the dialogue, in inquiring discourse, co-existance of questions and answers. Educational space is understood dialogically, not as a given but as being - potency. The educational process allows the connection of different people, their interactions, contacts, relationships. In the educational process is important in the immediate context, socio-cultural background, ideological attitudes of entering into dialogue, the distance between them. In the educational space, not two, but three components: teaching, learning and their attitude. Attitude plays a leading role, as the ratio of converts and student learning in intersubjectivity. Dialogue is not simply an indication of their relationship, the dialogue forms a new unity.

\section{References:}

1. Bakeeva EV (2014) Ontologicheskii kontekst ideologii reitinga // Vestnik Gumanitarnogo universiteta. 2014. № 3 (6). pp. 106-111.
2. Vaganova OI (2013) Tehnologija problemnogo dialoga v professional'nom obrazovanii // 


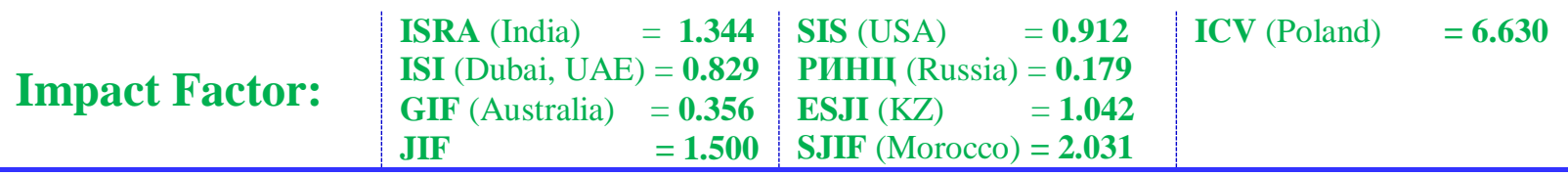

Vestnik Mininskogo universiteta. 2013. № 4 (4). pp. 10.

3. Kovalev GA (1993) Psihicheskoe razvitie rebenka i zhiznennaja sreda // Voprosy psihologii. - 1993. - №1. - pp. 13-23.

4. Lankin VG, Lankina EE (2012) «Mezhdu lichnost'yu i professiei: idei i problemy kompetentnostnogo pod hoda $\mathrm{v}$ vysshem obrazovanii» // Vestnik Tomskogo gosudarstvennogo pedagogicheskogo universiteta. 2012. № 11 (126). pp. 9-14.

5. Loginov AV (2013) Toleration: pro et contra // Vestnik permskogo universiteta. Serija Filosofija. Psihologija. Sociologija Vypusk. 2013, № 1 (13). pp. 44-49.

6. Novozhenina EV (2005) Strekturnye komponenty dialoga $\mathrm{V}$ professional'nom obrazovanii // Izvestija Volgogradskogo gosudarstvennogo tehnicheskogo universiteta. 2005. № 6. pp. 96-99.
7. Pesockii YS (2002) Vysokotehnologicheskaja obrazovatel'naja sreda: principy proektirovanija // Pedagogika. 2002. № 5. pp. 26- 35.

8. Ridings B (2009) Universitet v ruinah. Minsk: BGU, 2009. - 248 p.

9. Semenova YL (2011) Dialog kul'tur v bilingval'nom obrazovanii kak resurs formirovanija kommunikativnoi kompetencii uchashihsja // Obrazovanie i nauka. 2011. № 6. pp. 90-99.

10. Shutaleva AV (2007) Problema videnija V kontekste konstitutivnoi ontologii soznanija. Avtoreferat na soiskanie uchenoi stepeni kandidata filosofskih nauk. Ekaterinburg, Ural'skii gosudarstvennyi universitet imeni A.M. Gor'kogo, 2007. 24 pp.

11. Tomyuk ON (2014) Creativity and Lawmaking: Ontological Aspect // Journal of Siberian Federal University. Humanities \& Social Sciences 2014, № 8, volume 7, pp. 12931300. 